\title{
インフルエンザの母児免疫に関する研究
}

\author{
徐 慶一 郎* 街 風 喜 雄**

\section{STUDIES ON THE MATERO-FOETAL IMMUNIZATION AGAINST INFLUENZA}

\author{
KEIICHIRO JO and YOSHIO TSUMUJI
}

(受稿 8 月 27 日, 1962)

\section{まえがき}

妊娠中の母親にワクチンを接種し，本人のみならす， 新生览にむ積極的に免疫を与えようとする最児免疫の試

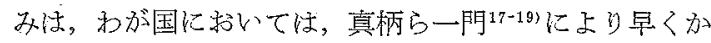
らとり亦げられた，その結果デフテリア，破傷風，ガス 壞㾝，ブドウ球菌の感染防止に，母親に詨するこれらの トキソイド免疫が有效であることが認められた，その際 母体に括的て産生された免疫抗体は出産時新生児によく 移行し，臍帯血中の抗体価は，概初母体血のそれに等し いか，時により高いことが認められた。妊娠中母親が自 然感染その他により既に高い抗体を有している時に新生 紧注出産時母親より受働的な免疫をえて感染を免加るる が，これを全く欠如する際新生児は出生直後から，疾患 感染の危険にさらされる.百日咳や破傷風などにおいて, 今日も庸子免疫が重要視されているのほ，自然の状態で 母体血中の抗体価が小量ないし，欠如し新生児が贯親よ り受働性免疫を獲得しにくい点にあると考えられる。

一方邱性疾患に执いては，多くの場合母親が自 然感染（多〉の場合不顕性感染）による抗体を有して掠 り，特にロクチン注射による母子免疫の必要を認めない ことが多い。しかし，一昨年，熊本県人吉市に㜿いてみ られたごとく，インフルエンザの流行に際して，一旦新 生児が罹患す尚々，非常に重症で，時に致死的でさえ㐫 る(木葉ら $\left.{ }^{14)}\right)$. 本例に执いては, 昭和 35 年 1 月 9 日加 ら 29 日の間に, 出生㨁後の新生児 16 名中 11 名が罹患, その 5 名が死亡している，この他，近代的設備を有する

* 関東违信病院隐床検查科

** 関東迎信病院锉婦人科

Microbiological Laboratory, and Department of Obstetrics \& Gynecology., Kanto-Teishin Hospital, Tokyo
大病院の新生児室においてウイルス性肺炎の流行が一度 抗こると，多数の犠牲者吕生ずる危険のあることは，過 去に肪いて多数経験されている，汃かる際，妊娠中の母 体を予め，積極的に免疫し，新生児に受動的な免疫を与 えてお汗ば，その災害加方免か和5る可能性法充分に期 待される処で, 今回の実験も，长のよらな出生面捘の新 生児に対する感染防止を第一の目的として試みられたも のである。

本実験を通じて，1)ワタチン接種による母体の免疫抗。 体産生

2)是体免疫抗体の新生児への移行

a) 抗体の種類による移行の難易

b)移行経路ないし移行機転（子宮内に打兴移行の経 路，母乳を通じての移行の可能性の有無)

などの諸問題を究明しよらと試みた。

インフルエンザ抗体としては，測定の容易で性状の明 から補体結合抗体ならびに血球凝集抑制抗体の両者を選 び，ウイルス免疫学的な検討を行なつた。

本報に䄧いては，1960年，1961年初頭に行なつた実: 験に関してえられた成績を報告する.

実験材料ならびに実験方法

\section{I. 免疫方法}

1）使用ワクチン a) $A_{1}$ (大町 $1 / 53$ 株) $A_{2}$ (足立 $2 / 57$ 株） B (世田谷 $3 / 56$ 株） 3 型混合普通ワクチンで，国家 検定に合格し, 市販されているもの（力価各型 $100 \mathrm{CCA}$ ) ml)，b） $A_{2}$ (足立株)，B (Lee 株) 2 型混合アジュバン ト加ワタチン（千葉血清研究所製インフルエンザ研発斑 用）で力価各型 $200 \mathrm{CCA} / \mathrm{ml}$ のもの.

2) ワクチン接種対象

関東遇信病院で需診中で妊娠 $8 \sim 9$ 力月の妊婦 1960 年 26 名, 1961 年 35 名につきワクチン接種が行なわれ 
t.

3） ワクチン接種方法

a) 3 型混合ワクチンを皮内 $0.1 \mathrm{ml}$ づつ $1 \sim 3$ 回, 2 週間隔で接種（1960 年）

b) 3 型混合ワクチンを初回 $1.0 \mathrm{ml}$ 皮下注射後 2 週間 閒隔で $0.1 \mathrm{ml}$ ら゙っ，1 2 回皮内追加注射(1961 年)

c) アジュバント加ワタチンを $0.5 \mathrm{ml}$ 皮下 1 回注射 (1961 年)

\section{II. 検体採取と保存}

血液ならびに初乳の採取, 保存.

ワクチン接種直前に母体血, 分婏時に母体血ならびに 臍帯血, 分婏後成るべき早期の母乳（初乳もしくはこれ に準ずるもの）を採取し，血液より血清を分離し，母乳 淁そのまま， $-20^{\circ} \mathrm{C}$ の冷凍器内に使用時まで保存した。

\section{III. 検体の処理方法}

1) 血清の処理 : 補体結合 (以下 $\mathrm{CF}$ ) 反応の際には, $56^{\circ} \mathrm{C}, 30$ 分加温, 非働化後使用, 血球凝集抑制 (以下 $\mathrm{H}$ I) 試験には，3倍量コレラ菌 (558 株) 培養口液 (力価測 定气の 2 単位を使用）を加え， $37^{\circ} \mathrm{C} 16$ 時間放置後 $56^{\circ}$ C 30 分非働化して使用.

2）母乳の処理：母乳 $10 \mathrm{ml}$ とクロロホルム $5 \mathrm{ml}$

（もしくはその割合に）スクリューチューブに入れよく 振とう, 次に Difco Rennin $5 \%$ 液を $0.5 \mathrm{ml}$ 加光振と 亏， $37^{\circ} \mathrm{C} 1$ 時間，恒温槽に放置後， 3000 r.p.m 15分閒 臺心する. 上層 (乳漿), 中層 (脂肪層), 下層 (ク口口禾 ルム層)の三層に分礼るので，ピペットで上層を分離す る(Stokers ら ${ }^{22)}$. 次に，コレラ菌 558 株培養口液で血 清と同様汇処理 $56^{\circ} \mathrm{C} 30$ 分非偅化後, HI 試験に使用乙 t.

\section{IV. 反応術式}

1）補体結合反忘：

$\mathrm{V}$ 抗原： $A_{2}$ (足立株) B (世田谷株)を 10 日発育鶏卵， 脽疗胵内接種 48 時間後の漿尿液を採取供用.

$S$ 抗原： $A_{2}$ (足立株) $B$ (世田谷株) 感染漿尿膜 $10 \%$ 燐 酸緩衝生食水乳剂を 10,000 r.p.m 30 分遠心，上清を分 離し，更に低温でニワトリ血球を作用させ，ウイルスと 吸着させた後，低温遠心しその上清を使用。

補体結合反応術式としては，小試験管を用いた，総量 $0.6 \mathrm{ml}$ の小量法 (米国陸軍々医学校法変法)を使用し t.

なお，CF 抗原価の測定は，患者血清の中でV抗体， Sおよび抗体価の高いむのを選び，各小量宛分注保有 し，これを標準血清とみなして，VならびにS 抗体との 間に boxtitration を行ない，各抗原の力価を測定その 2 単位老使用した。
2）血球凝集抑制試験術式

血球凝集素しして，インフルエンザ $\mathrm{A}_{2}$ (足立株) およ びB (世田谷株) 両株の感染漿尿液を使用, プラスチック 板 (80 穴) を用いた. 総量 $0.8 \mathrm{ml}$ の標集術式により抗 体価測定を行なった。

\section{実験成績 :}

A. 補体結合抗体測定成綪

1）ワクチン接種による CF-V ならびに CF-S 抗体 価の上昇 (図 $1.2 ， 3 ， 4$ )

1960 年度 CF.V 抗体 (26 組) CF-S 抗体 (24 組)，1961

Fig. 1 Flu-CF-V Antibody Titer (1960)

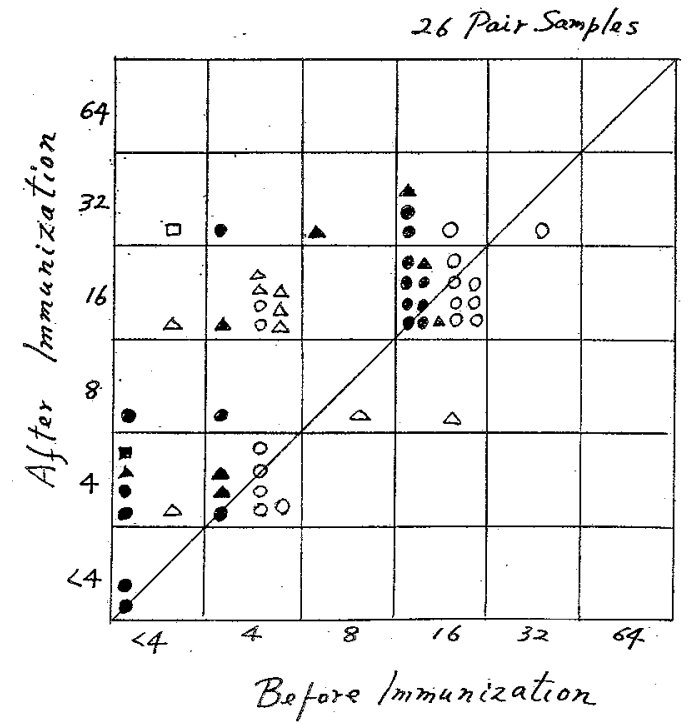

Fig. 2 Flu-CF-S Antibody Titer (1960)

24. Paur Samples

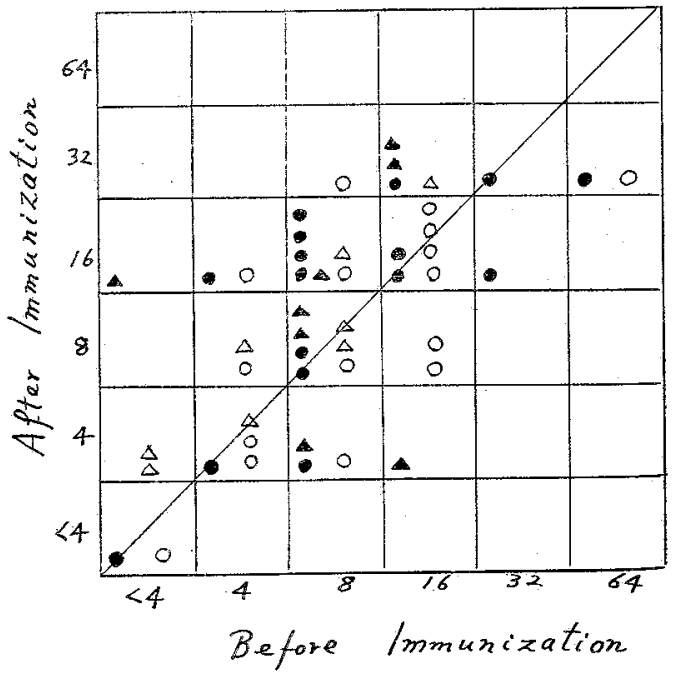


Fig. 3 Flu-CF-V Antibody Titer (1961)

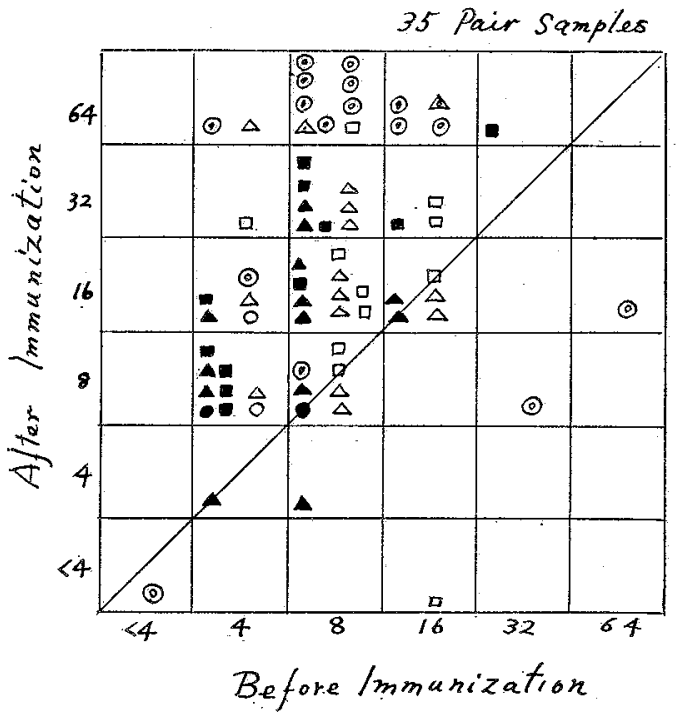

Fig. 4 Flu-CF-S Antibody Titer (1961)

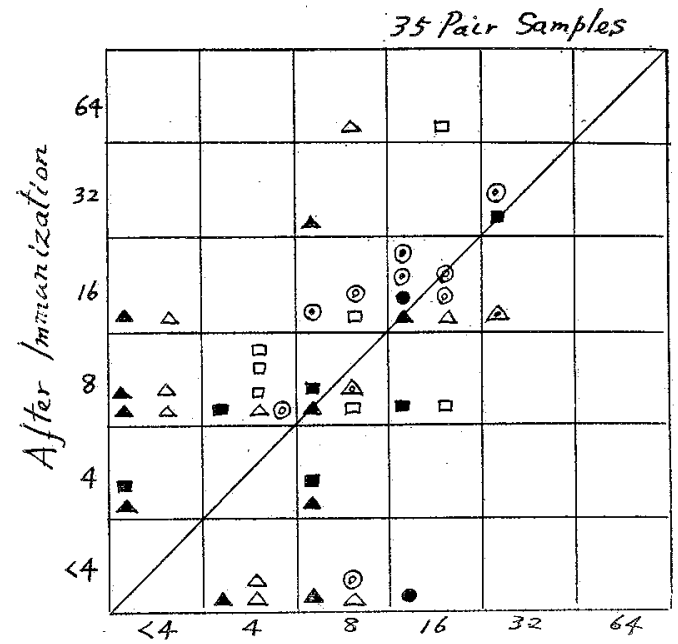

- $0 \Delta 0$

- $\div$ O 0 (0)

- $\Delta \Delta$ a

$\Delta \circ \Delta a$

- $0 \Delta a$

年度 CF-V 抗体 (35 組) CF-S 抗体 (35 組)についてワク チン接種前後の動きか, 図1，2，3，4に示されてい る.図中黑丸はA型抗体，白丸はB型抗体を示し，丸は 1 回，三角忙 2 回，四角は 3 回，2 重丸はアジュバント 加ワクチン接種を示している.

CF-V 抗体は 1960 年, 1961 年度ともに上昇が認めら れるが，1961 年度は 1960 年度に較心゙上萃率が著明であ り，特にアジニバント加ワクチン接種者では，その上昇 度の著明なことが認められた。
CF-S 抗体は，両年度ともワクチン接種による上昇が 認められず，特に 1961 年度に和いては，A 型ないし B 型両抗体ともその $1 / 3$ が陰性 (1:4 以下) にとどまつた. CF-S 抗原は使用ワクチンに含まれていないから，ワク チン接種による抗原の動き牥るれないのが当然で本抗 体の変動は自然感染によるものと考えられる.

2） 母体血と臍带血の CF-V および CF-S 各抗体測 定值の比較. (困 5, 6, 7,8,9, 10)

Fig. 5 Flu-CF-V Antibody Titer (1960)

Inmunized Group 25. Pair Samples

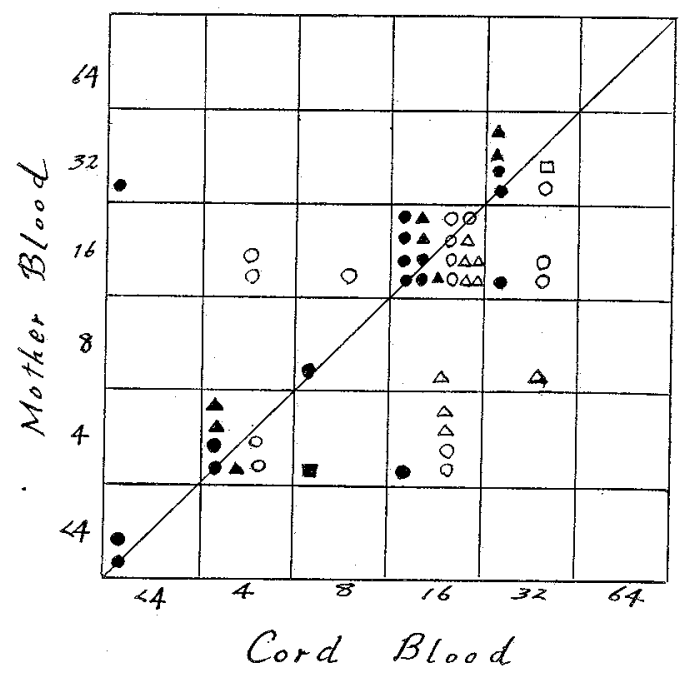

Fig. 6 Flu-CF-S Antibody Titer (1960) Immunized Group 25 Pair Samples

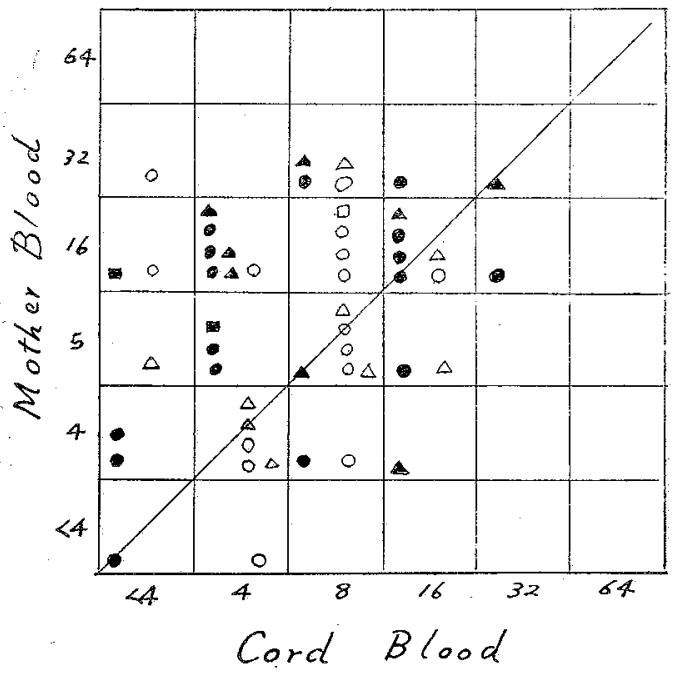


Fig. 7 Flu-CF-V Antibody Titer (1961)

Immunized Group 35 Pair Samples

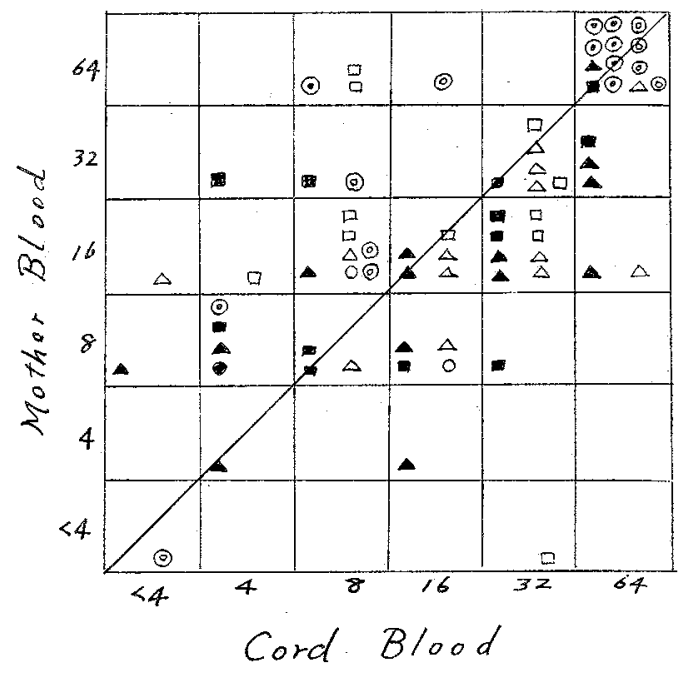

Fig. 8 Flu-CF-S Antibody Titer (1961)

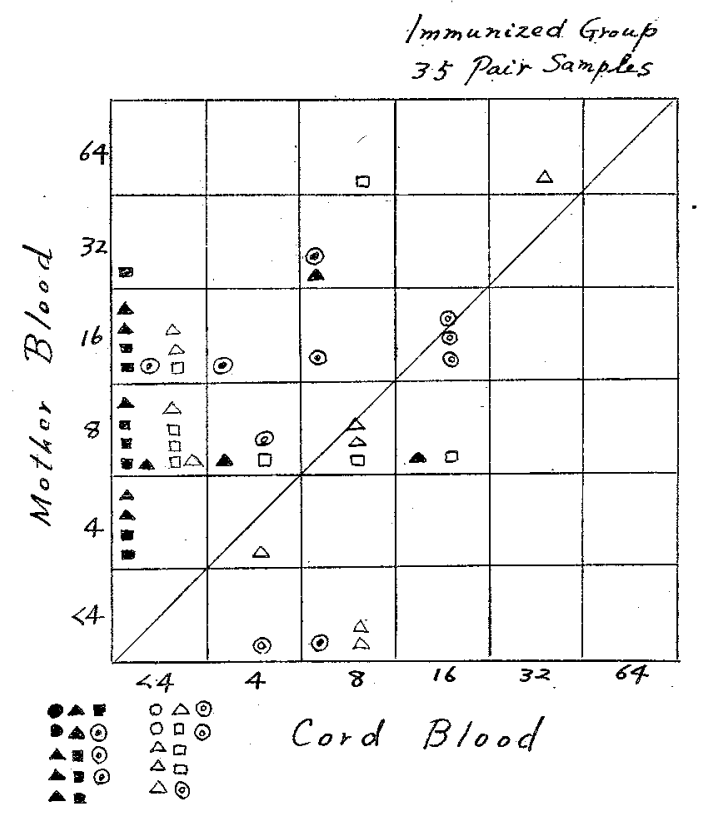

1960 年, 1961 年, ワクチン接種の各 25 組ならびそ 35 組，1961 年，ワクチン未接種対照の 22 組の母児血清に つき，CF-V ならびに CF-S 抗体価の測定が行なわれ た。攵の結果，CF.V 抗体の場合は，ワクチン接種の有 無に関係なく，両年度ともとの值が等しいか，むしろ臍 帯血に高めにでた。特に 1960 年免疫群(図 5 ) と 1961 年 (図6)にその傾向が明かであうた。
Fig. 9 Flu CF-V Antibody Titer(1961)

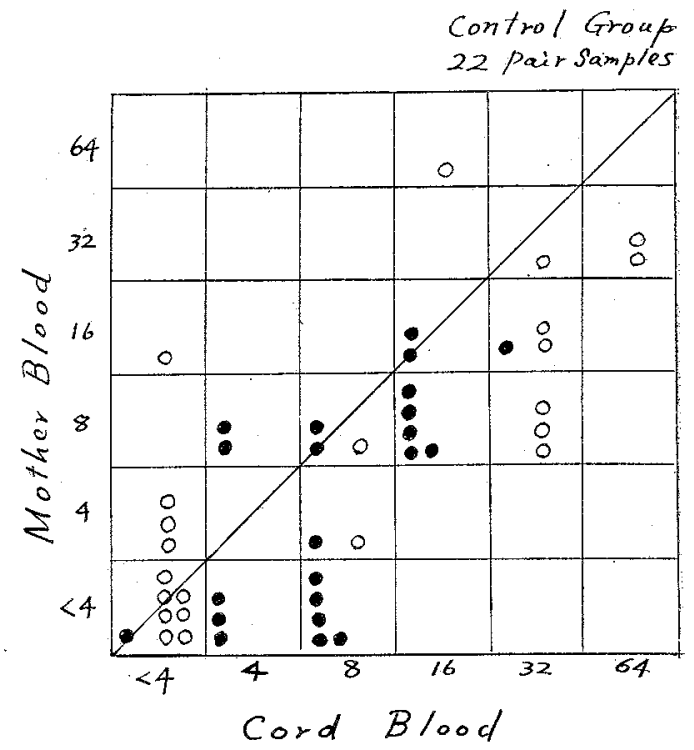

Fig. 10 Flu-CF-S Antibody Titer(1961)

Control Group 22 Pair Samples

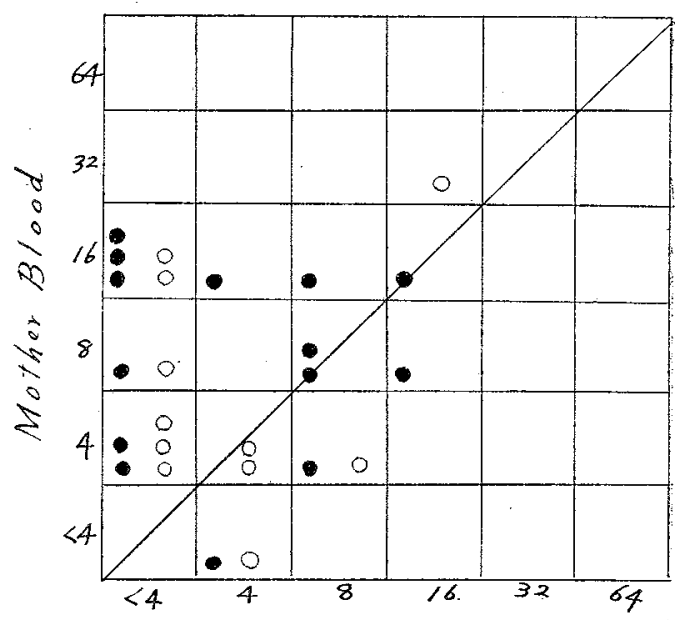

$\because 000$ Cord Blood $\because 00$ 00

反之，CF-S 抗体に関しては，母体血と臍带血の值务 等しいか，母体側に高い傾向が認好方れた（図 $6,8,10$ )

B. 血球凝集抑制抗体測定成綪

1）ワクチン接種による $\mathrm{HI}$ 抗体価の上昇(図 11，12) 1960 年, 1961 年各 26 組, 32 組のワクチン接種前後の 血清につき $\mathrm{HI}$ 抗体価が測定された。 その結果, ワクチ ン接種により母体血中に注，両年度とも明膫な $\mathrm{HI}$ 抗体 
Fig. 11 Flu-HI Titer (1960)

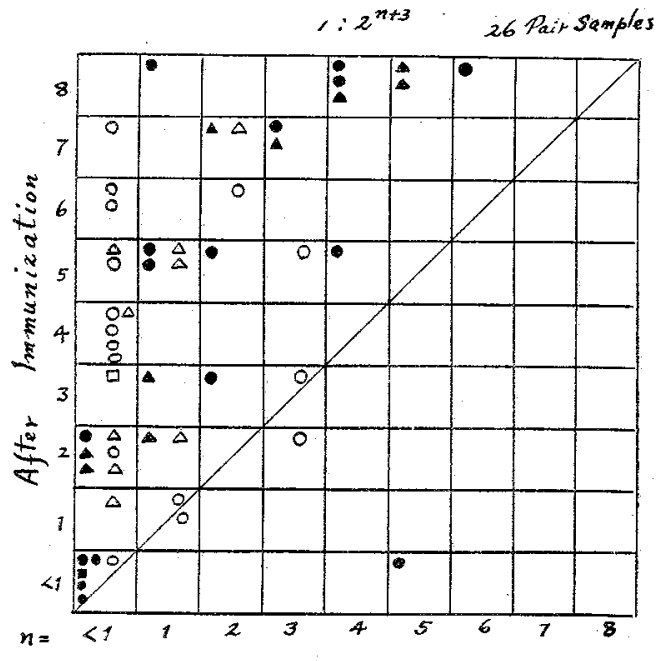

Before Immunization

Fig. 12 Flu.HI Titer(1961)

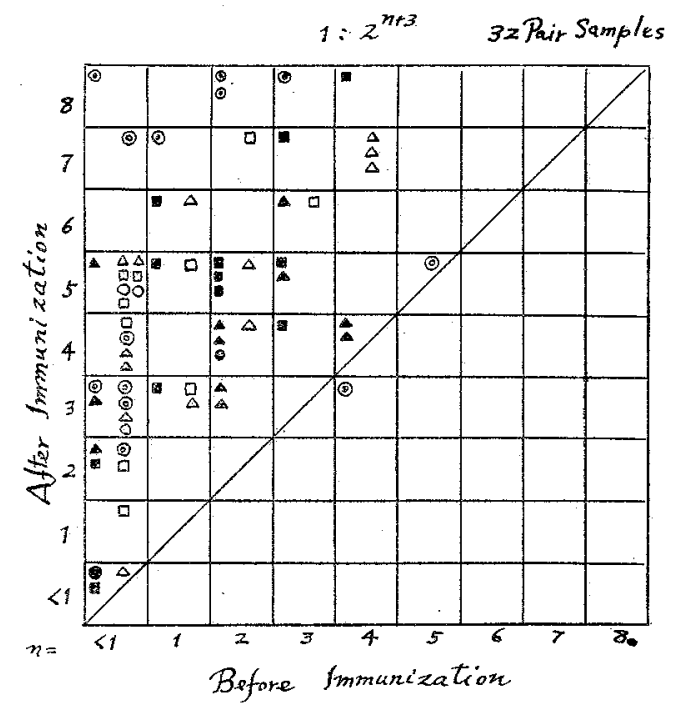

洒の上昇が認められ，特に1961 年度アジュバント加り クチン接種者群については，その上昇度が著しかった。

（図 12 の 2 重丸）

2]母体血と臍帯血の HI 価測定値の比較（図 13，14 15)

1960 年，1961 年，免疫群の 各 25 組ならびに 35 組お よび 1961 年ワクチン未接種対照群の 22 組の母児血清に つき，HI 価測定が行なわれた，その結果母体血と臍体 血の HI 抗体価は，免疫の有無に拘敄らず，よく相関し 雨者の值のほぼ等しいことが明かにされた. 1960 年度に
Fig. 13 Flu-HI Titer(1960).

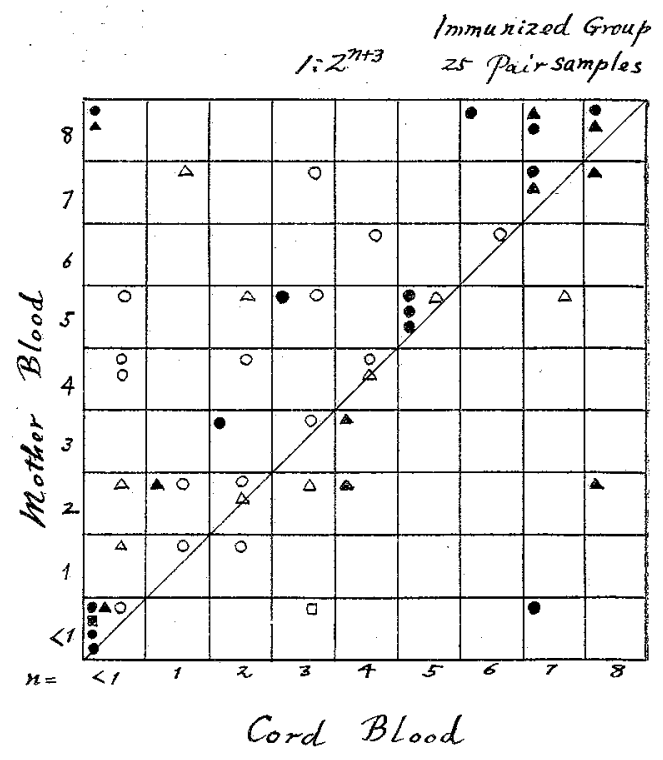

Fig. 14 Flu-HI Titer(1961)

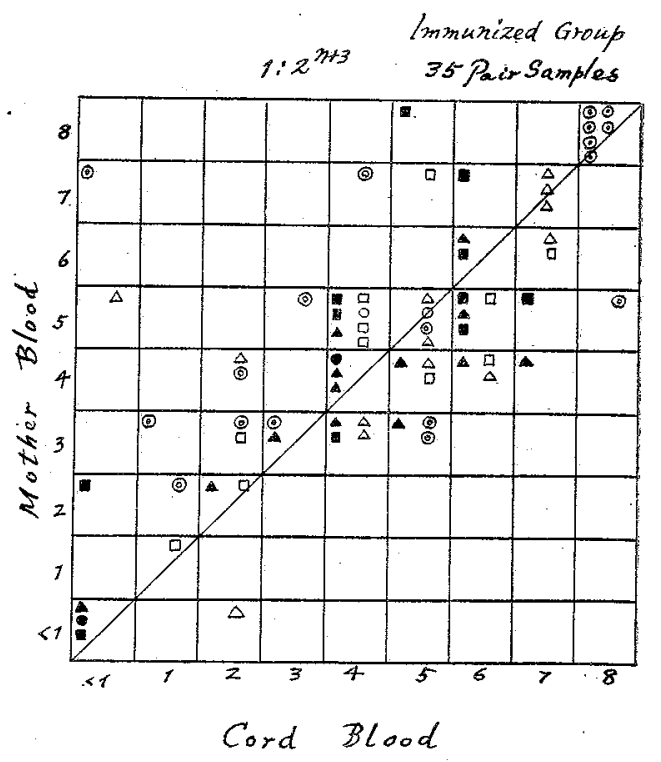

おいては，その測定值のバラツキが大きく，母体血にや や高い值が示された。

3）初乳に和计る $\mathrm{HI}$ 抗体の検出(図 16，17)

1961 年免疫群 31 組, 対照群 22 組の各母児血清につき HI 抗体価測定が行なわれた。 その結果，1961 年免疫群 の 31 例中 22 例に $\mathrm{A}_{2}$-抗体，5例にB抗体が検出され， また対照群にも，19例中 9 例に $\mathrm{A}_{2}$ 抗体，2例にB抗体 が証明された，免疫群と対照群の值を比較すると，免疫 
Fig. 15 Flu-HI Titer (1961)

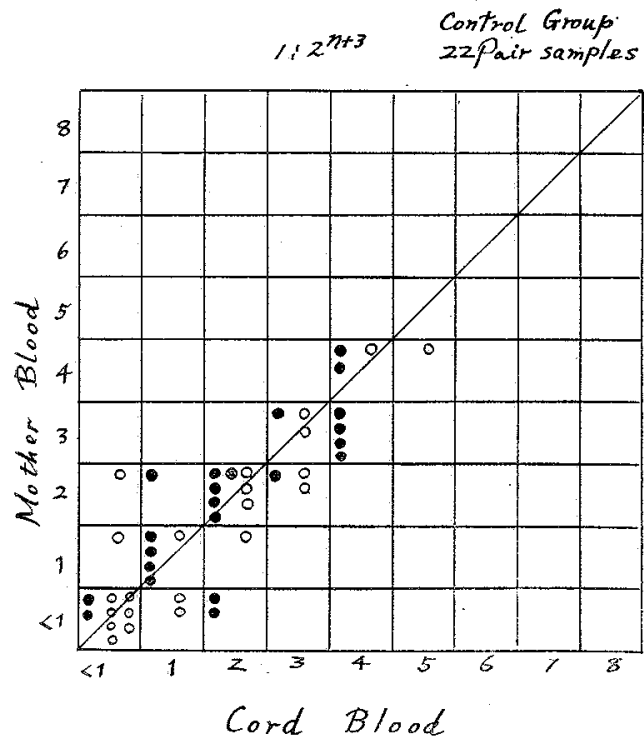

Fig. 16 Flu-HI Titer (1961)

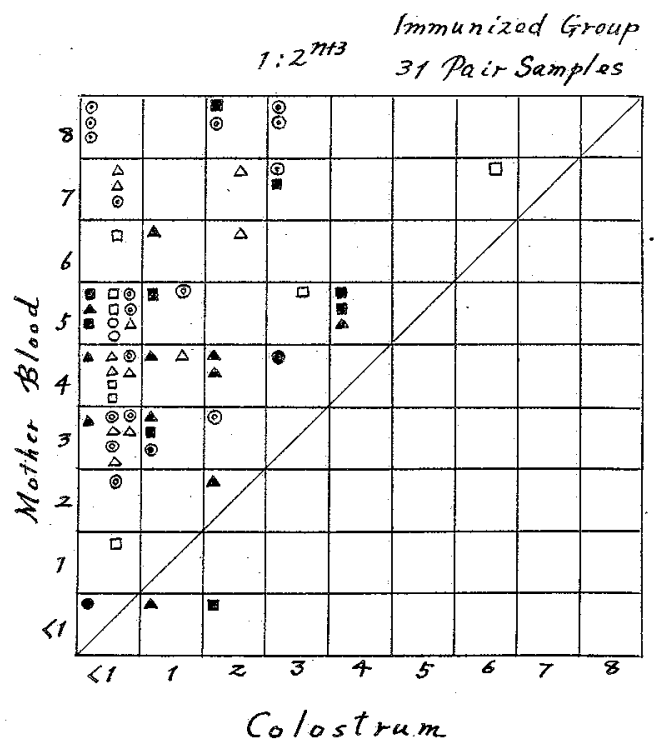

群において，その陽性率が高く，その值も高かつた。し かし，免疫群の母体血のHI 価は，対照群のそれに比し 著して高いに拘わらず，免疫群の初乳中の HI 価は，対 照群のそれに比し，高くはまるにしても，その差功著明 でなく，また，母乳血中と初乳中の HI 価の相関性注明 蹽ではなかつた。

\section{考按}

インフルエンザウイルスに対する個体の免疫ないし感
Fig. 17 Flu-HI Titer (1961)

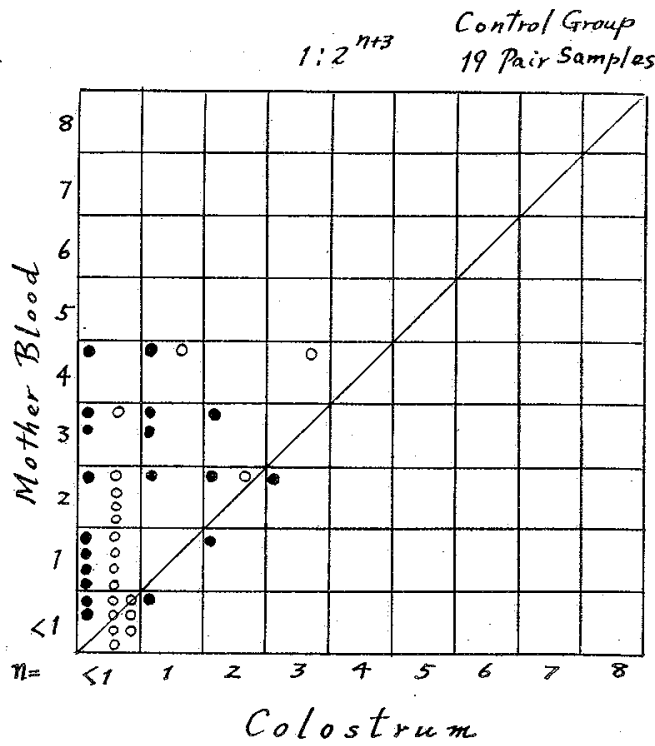

染防禦力の全てが，血中抗体により表示されるものとは 断言できないが，過去に特けるインフルエンン年の流行や 多くの実験に示されたように，一定量以上の血中抗体 (HI 抗体では1：64以上）功存在されば，該ウイルスの 侵入に際し，感染防禦の成立寸ることが明かにされてい る (Fukumi $\left.{ }^{7}\right)\left(\right.$ Hillman $\left.~^{8)}\right)$.

今日の実験において，妊娠 $8 \sim 9$ 力月の母親に現行市 販ワクチン $(100 \mathrm{CCA} / \mathrm{ml}$ 力価のもの) を皮下 $1.0 \mathrm{ml}$ 後 皮内に $0.1 \mathrm{ml} ， 1 \sim 2$ 回 2 週間隔で注射を行なつた場 合，あるい惊ジュバント加ワクチン $(200 \mathrm{CCA} / \mathrm{ml}$ 力 価） $0.5 \mathrm{ml}$ を皮下一回注射した場合，分婏時に母親血

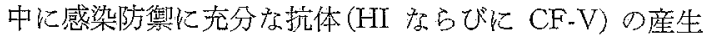
が認められ，特にアジュバント加ワクチン接種者におい て諸報告(佳野 ${ }^{24)}$ )に文られるように免疫抗体産生率が著 明であつた，また同時に，臍帯血中にも，これに相応す る抗体の存在が証明され，母親と同じ程度に新生児にも 充分な免疫力附興しうることが明为にされた。その際 母体血と臍带血中抗体価を比較してみると, 抗体の種類 により，雨者の等しい場合，前者吕後者より高い場合， この反対に，後者が前者より高い場合汃認められた。守 なわち HI 抗体では，両者に若干差があるにしてる概し てその価がほぼ等しいが，CF-F 抗体では；どちらかと いえば，臍带血に高く，CF-S 抗体では，舟体血に高い ことが認められた。

このような現象は，目体にりタチン注射を行なっなか つた対照群に执いて認められた。

インフルエンザ免疫抗体の母体加ら新生児への移行に 
関しては，古くは Burnet (1938)，平野 $\left(1941^{91}\right)$ ，良田 $\left(1938^{27)}\right)$ の中和抗体に関する報告があり，良田は，臍帯 血亡母体血の抗体価妾比較し，前者に高かつたと述べて いる、また尾辻 $\left(1952^{209}\right)$ は母体血と臍带血ならびに母乳 中の HI 価を測定し，HI 抗体は胎盤を通じて，完全に新 生児に移行するが，母乳には移行しないと述へている。

次にひと以外の動物に関しては，Young ら $\left(1950^{25)}\right)$ は豚インフルエンザ抗体が母親豚から初乳を通じて新生 仔に移行することを述べている. 北岡ら $\left(1956^{12)}\right)$ はイン フルエンザ $\mathrm{A}_{1}(\mathrm{FMI})$ のI 抗体は母親ラッテから新生仔 へ，胎盤を介して移行子るが，その抗体価注母ラッの 1/4程度であると述心ている。しかし，ラッテの場合は， 発疹チフス発疹熱 CF 抗体徐 $\left(1953^{11)}\right)$, 日本脳炎中和抗 体石黒 $\left(1959^{107}\right)$ の実験に示されたごとく, 生後, 母乳を 通じての移行が，胎盤移行より以上に重要視され称ばな らないであるう。

以上インフルエンザ抗体についても他の多くの抗体で 示されたように動物物種類により移行の経路が異つてお り，ひとの場合は，胎盤通過ないし子宮内での移行が主 な経路であり, 初乳を介しての移行は現在まで否定的で あつた。

今可の実験において，母乳乳漿中に見出された血球凝 集抑制物質は，RDE 処理で消失しないところから，一 応 non specitic Inhibitor とは考光られないが，抗体と しての特異性状については，更に検討の要があるら。ま た, 乳漿中の本抗体の消長ならびに, 本抗体の新生览腸 管からの吸収の可能性については実験索重视る要がある 5 .

次に，子宮内に扔いて抗体の移行の問題であるが，ひ とは hemochorial type の胎盤存し，一応抗体の移行 が胎盤を通じて容易に行なわれるとされているが，抗体 の種類により，移行度に難易があり，それは単なる拡撒。 によるもので汭いことが認められている。すなわち， 動物実験によれば，同し凝集素や溶血素でも，homologous の抗体は移行するが, heterugous のものは移行せ す，その際抗体の大きさのみには関連しないことから， 胎盤の細胞には, Selective Function が考えられる。 (Calman $ら^{4\rangle}$ ). また, 同じ腸チフスの凝集素でも，H 凝集素しO凝集素では, 胎盤移行性に差がタ一ら (Smith ${ }^{22)}$ )，前者は移行しないことが認められている。更に串り オの中和抗体について各型の間に，移行性に差のあるこ とが指摘されている. (Lipton ら ${ }^{15)}$

Rh-凝集素については，不完全抗体は完全抗体より通 過性が容易で (Coomb ら゙) これと同様なことはニワト リのサルモネラ抗体 $\left(\right.$ Buxton $\left.^{3 \prime}\right)$, ひとの結核菌抗体（進 藤 $1957^{25)}$ )，などについても証明されている。
また，母児間に移行のみられる抗体につき，母体血と 臍帯血抗体価を比較すると胎児側に抗体価の高いこと

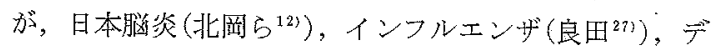

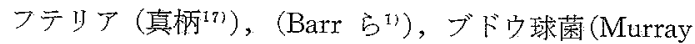

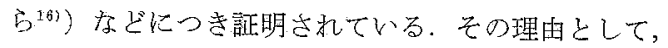

1）臍带血中に非特異的な抗体が存在し, 特異抗体に 加わつて高くでる $\left(\right.$ 真柄 $\left.{ }^{18}\right)$.

2）妊娠中に免疫する際には，抗原が胎坚に移行，胎 児に招いて抗体方産生される(真柄 $\left.{ }^{9}{ }^{9}\right)$.

3）母体抗体ががそのまま移行するのでなく，その抗 体が，特異的な部分を残してある程度分解されて胎児に 移行し，胎児体内で特異抗体に再合成される（Calman $5^{(1)}$ ).

4) 抗体が羊水内に移行し，胎児がこれを吸飲濃縮す る(Brambelli2).

などの考えがある。

何れにしても子宮内に和ける抗体の移行は単なる胎盤 通過以外に種々の可能性が考えられ，その機構汢複雑な ことが考えられる。

\section{結，論}

妊娠 8〜9力月の妊婦 1) に市販インフルエンザ $\mathrm{A}_{1}$, $\mathrm{A}_{2}, \mathrm{~B}$ 混合ワクチン (100 CCA $/ \mathrm{ml}$ 力価) 皮内 $0.1 \mathrm{ml}$ つ2 週間隔で 1 〜 回 2) ワクチンを皮下 $1.0 \mathrm{ml} 1$ 回 後, 皮内 $0.1 \mathrm{ml}$ づつ, 2 週間隔で $1 \sim 2$ 回 3) $\mathrm{A}_{2}, \mathrm{~B}$ 両 型混合アジュバトト加ワクチン $(200 \mathrm{CCA} / \mathrm{ml}$ 力価 $) 0.5$ $\mathrm{ml} 1$ 回注射し, 注射前後の母体血, 分婏時の母体血, 㕶带血, 初乳を採取し, CF-V, CF-S, HI 抗体価の測定 を行なつた。

その結果母体血中には，CF-V, HI 抗体価の上昇が認 められ, 特に普通りクチン皮下 1 回に, 次いで皮内 2 回接 種の場合，あるいはアジュバントワクチン接種者では著 明であつた。CF-S 抗体は, 反之, 上昇が認められなかつ た. 臍帯血中に柱母体血よりやや高い価の CF-V 抗体, やや低、価の CF-S 抗体，またほぼ同值の HI 抗体が証 明できたまた，初乳中にも母親血より低い值の $\mathrm{HI}$ 抗 体(推定)が証明できた. 以上の結果が方妊娠 $8 \sim 9$ 力月 の妊婦にインフルエンザワクチンを接種することによ り，積極的に新生巟に免疫を与光らることが証明され た。

本諭交の要旨は, 第 13 回日本産婦人科学会総会, 第 34 回日本伝染病学会総会 並びに第 9 回日本ウイルス学 会総会に指いて発表学行つれ.

本研究の奏施に祭し, 北里研究所五十嵐技士, 群馬中 央病院，高橋技士，当院，臨床検查科，産婦人科各医局 員つ技術的援助を得たので，深謝します。 


\section{Summary}

For the purpose to prevent the serious influenza infection among newborns, the following experiment to testify the possibility of the materno-fetal immunization against influenza were performed. Pregnant women at their 8-9 th month of gestation were injected with commercial trivalent (A1, A2, B) type vaccine and adjuvant added bivalent (A2, B) type vaccine, specially prepared by Chiba Serum Institute for experimental purpose. These vaccine have the potency of $100 \mathrm{CCA} / \mathrm{ml}$ and $200 \mathrm{CCA} / \mathrm{ml}$ per each type, respectively. The mother bloods taken just before the injection and at delivery, and cord bloods and colostrum collected at delivery were tested for their contents of influenza CF.V, CF-S and HI antibodies.

As the results, the increase of $\mathrm{CF}-\mathrm{V}$ and $\mathrm{HI}$ titer in the mother bloods were observed after vaccine injection, especially when subcutaneous $1 \mathrm{ml}$ injection following two intradermal $0.1 \mathrm{ml}$ injection of routine commercial vaccine, or when $0.5 \mathrm{ml}$ adjuvant added vaccine were injected subcutaneously. On the contrary, the increase of CF-S titers were not observed.

In the cord bloods somewhat higher titers of CF. $\mathrm{V}$, somewhat lower titers of CF-S and nearly equal titer of HI antibodies were demonstrated, as comparing with those in the mother bloods.

In the mother colostrum, HI antibodies of lowere titers comparing with those of mother bloods were demonstrated.

From above data it became evident, that the materno-fetal immunity against influenza is completely established by active immunization of pregnant women at their 8-9 th month of gestation.

\section{文 献}

1) Barr M. Glenny A.T. and Randall K.J. (1949) : Concentration of diphtheria antitoxin in cord blood, and rate of loss in babies. Lancet 2, 324-326. -2) Brambell F. W. R, Holliday R. Brierley J and Hemming W.A. (1954) : Transference of passive immunity from mother to young. Lancet 1, 964-965. -3) Buxton A (1954) : On the transference of bacterial antibodies from the hen to the chick, J. Gen Microbiol. 10, 394-410. -4) Calman R. M and Murray $\mathrm{J}(1951)$ : The transfer of antibodies across the placenta. Endeavour, 10, 27-32. -5) Coombs R. R. Mourant A. E. and Race RR(1946): In vivo isosensitization of red cells in babies with hemolytic disease. Lancet, 1, 264-266. --6) Dean D. J. (1952) : Postnatal immunity in mouse Encepealomyelitis, J. Immunol. 68, 549-557. -7) Fukumi H. (1959) : Human vaccination experiments with asian influenza vaccine in Japan. Bull. W. H. O. 20, 355-376. 8) Hillman M.R. Flathey F.J. Anderson S A and Leucking M. L. (1958) : Antibody response in volunteers to asian influenza vaccine. J A M A 166, 1134-1140，一9）平野憲正（1941）：新生塄の免疫に 就て, 血清学免疫学雑誌, $2,295-306 .-10)$ 石黒和 彥 (1956)：日本脳炎抗体の母親ラッテから新生伎口 の移行に関する研究, ウイルス，6，112-[21. - -11) IO. $\mathrm{K}(1953)$ : on the transmission of antibodies $\mathrm{fr}$ om mothers to their offspings in experimental typhus fever Experiments in albinorats and guinea pigs. Jap. J. Med. Sci \& Biol. 6, 299-310. -12) 北 岡正見，三浦悌二(1950)：新生児とその母親血清の灰 白髄炎並下日本脳炎病毒飞刘吉る中和抗体について, 新生兒臍带血飞和引中和抗体の濃縮現象，䀢学々 生物学，17，171-173. -13) 北岡正見, 石黑和苶 (1956)：インフルエンザウイルス A' (FMI) で兔疫し た母親ラッテとその新生仔との.血球凝集版制抗体の 比較, コレラ菌培養濃度に上る非特異凝集 抑制物質 の除去, ウイルス，6，99-102. -14）木葉矩弘, 山 下馨(1961)，当病院飞集団発生した新生览肺资に就て， 第 13 回日本産婦人科学会総会報舫. - - 15) Lipton M M. and Steigman A. J(1957) : Neonatal Immunity I Disparity in maternal infant poliomyelitis antibody. Proc. Soc. Exp. Biol \& Med 96, 348-352. 16) Murray J. Calman R. M and Lipin A (1950): Transmission of staphylococcal antitoxin from mother to ceild. Lancet 2，14-16. - -17) 真唡正直, 小

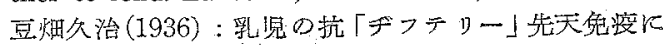
ついて，奏験医学雑誌，20，1517-1607. -18) 真柄 正直 (1942)：母棁免疫について, 医学の進步, 第 1 輯，143-167，- -19）真柄正直，山田道生（1954）：母 見兔疫，綜合医学，11，161-163. 一-20）尾过春三 (1952)：ハーストテストによる新生見血清及び母乳 の中和抗体について，医学研究，22，145-. - 21) Parish H. J. (1951) : Inherited immunity Brit Med J. 2, 1164-1168. -22) Smith R.T. (1960) : Response to active immunization of human infants during the neonatal period. Ciba Foundation Symposium on Cellular Aspects of Immunity J. and A Churchhill, London, 348-358. -23) Stoker M. G. P. and Marmion B.P. (1952) : Detection of 2 fever antibodies in whey by the antiglobulin sensitization test and other technique J. Hyg. 50, 1-11. -24) 佐野一郎 (1961)：流感の予防，䛦断飞治潦，49, 877 -883. 一25) 市川洋一 (1957)：結核の不完全抗体の研 究と新しい不完全抗体証明法について, 目細菌誌, 12, 389-395. -26) Young G.A. and Underdahl N.R. (1950) : Neutralization and hemagglutination inhibition of swine influenza virus by serum from suckling swine and by milk from their dames J. Immunol 65，369-373. - 27) 良国圭子 (1938)：人血清 を以てせるインフルェンザウイルスの中和試験，東 京女医学会雑誌, 8,54-62. 